\title{
Small Is Beautiful? A Comparison of Major and Minor Credit Rating Agencies Credibility
}

\author{
Paola De Vincentiis ${ }^{1} \&$ Patrizia Pia ${ }^{1}$ \\ ${ }^{1}$ Department of Management, University of Torino, Torino, Italy \\ Correspondence: Paola De Vincentiis, Department of Management, University of Torino, 10124 Torino, Italy.
}

Received: November 16, 2016

Accepted: December 6, 2016 Online Published: December 19, 2016

doi:10.5430/ijba.v8n1p1

URL: http://dx.doi.org/10.5430/ijba.v8n1p1

\begin{abstract}
The events linked to the subprime crisis undoubtedly damaged the reputation of credit rating agencies (CRAs), at least in the short and medium-term. In this paper, we intend to gauge the extent of that reputational damage by examining the reaction of the market to rating actions. Using a standard event study methodology, we measure the abnormal return of stock prices in the three-day window centred on the announcement day during the period November 2003 - November 2013. Our theory is that the market reaction to downgrades, upgrades and credit watches is lower - after the crisis - than it used to be due to a lack of trust in the neutrality and reliability of the rating agencies. We expect the phenomenon to be more pronounced for the three major CRAs - Moody's, Standard \& Poor's and Fitch - who had more direct involvement in the scandal. For the minor players, the impact of the crisis is potentially twofold. On one side, they may have suffered from a general mistrust of the rating industry. On the other side, they may have benefited from a higher level of attention from investors in search for a cross-check of opinions.

The evidence strongly supports the theory of a lower market reaction to rating announcements, especially for the three major agencies. The abnormal returns of equity prices in an event window of a rating action are significantly lower after the crisis than they were before, after considering various explicative factors relating to the features of the announcement and the market conditions in terms of volatility. In line with previous literature on the topic, we find that, due to the "certification" role that many regulations grant to rating agencies, the abnormal return is stronger when the valuation is near to the border between investment and speculative grade. As a consequence, where the certification role is prevalent, there is no difference in the market reaction to announcements before and after the crisis. Conversely, the cumulative abnormal return is significantly lower after the crisis when there is no "regulation-induced" trading and the market investors' behaviour is predominantly guided by the faith put in the informative content of the rating.
\end{abstract}

Keywords: credit rating, event study, reputation, market efficiency

\section{Introduction}

After the so-called subprime crisis, the climax of which was reached with the default of Lehman Brothers, one of the main scapegoats chosen by academicians and supervising authorities were rating agencies. In fact, during the turmoil, their evaluations of the collateralised debt obligations (CDOs) and similar securities proved to be extremely poor and unreliable. In the space of a few months, thousands of bonds were rapidly downgraded from AAA to junk level (Note 1). The same happened to many banks deeply involved in the securitisation market, both as originators and investors. In the aftermath of the crisis, various critical analyses and several trials focused on ascertaining the responsibilities of credit rating agencies (CRAs) and the roots of a disastrous performance that was unprecedented in their history. A mixture of conflicts of interest and excessive workloads emerged as the most probable factors underlying the widespread overvaluation of structured finance products. As a consequence, an international debate developed over the role of rating agencies, the need to limit their regulation-related power and the drawbacks of the issuer-pay business model.

The events linked to the subprime crisis undoubtedly damaged the reputation of rating agencies, at least in the short and medium-term. The conclusions drawn by the US National Commission on the causes of the financial and economic crisis focus extremely heavily on the point and reflect similar opinions expressed by other authoritative observers: "We conclude that the failures of credit rating agencies were essential cogs in the wheel of financial 
destruction. The three credit rating agencies were key enablers of the financial meltdown. The mortgage-related securities at the heart of the crisis could not have been marketed and sold without their seal of approval. Investors relied on them, often blindly. In some cases, they were obligated to use them, or regulatory capital standards were hinged on them. This crisis could not have happened without rating agencies" (Financial Crisis Inquiry Commission, 2011, p. 25).

In this paper, we intend to gauge the extent of the reputational damage suffered by CRAs by examining the reaction of the market to their rating actions. Using a standard event study methodology, we measure the abnormal return of stock prices in the three-day window centred on the announcement day during the period November 2003 November 2013. Since the poor performance of rating agencies during the subprime crisis primarily affected the financial sector, we focus our attention on a sample of major international banks belonging to the Stoxx 1800 Index (Note 2). Furthermore, we distinguish the rating actions announced by the three main CRAs - Moody's, Standard \& Poor's and Fitch - who had more direct involvement in the scandal and in the ensuing inquiries, from those emanated by other minor agencies.

We expect to find a lower market impact of rating actions after the crisis, due to a loss of trust in the neutrality and reliability of the rating evaluations. In other words, we expect the market will believe less blindly and, consequently, react less strongly to rating agencies' credit opinions. In particular, we expect the phenomenon to be stronger when the certification role is less significant and, thus, the regulation-induced trading is more scant. As regards the type of agency, we expect to find a lower market reaction and, thus, reduced trust in the rating actions announced by the three majors. For other agencies, the effect of the crisis is less clear-cut. On one side, they may have suffered indirect reputational damage, due to the lower perceived reliability of credit evaluations issued by private issuer-paid raters. On the other side, they may have benefited from the weaker oligopolistic power of the three majors and from their cleaner track record.

The remainder of the paper is organised as follows. In section 2 we start with an analysis of the role and some criticisms of credit rating agencies, followed by a discussion of the antidotes devised by the regulations in the aftermath of the crisis in order to prevent similar problems occurring in the future. In section 3 we review the literature on the topic. In sections 4 and 5 we describe the empirical analysis conducted by detailing the criteria used for selecting the sample, its composition, the method used to calculate the abnormal returns and the variables used in their econometric analysis. Section 6 presents an analysis of the determinants of abnormal returns for the rating actions announced by Moody's, Standard and Poor's and Fitch. The weight of various factors is taken into consideration in the empirical investigation: the kind of rating action, the extent of the rating change in terms of number of notches, the potential crossing of the border between investment and speculative grade, the distance from a previous rating action by the same or another agency. To all these - quite standard - independent variables, we add a dummy variable representing the period in which the announcement was disseminated to the market: before and during the subprime crisis or in the post-crisis period. For our research question, this temporal dummy is the main focus of interest and is the instrument through which we gauge if the market has been reacting differently to rating announcements since the subprime turmoil cast shadows over the reliability of the agencies. Section 7 repeats the analysis on the sub-sample of rating actions announced by all other minor agencies who had less direct involvement in the turbulent subprime crisis. A specific focus of the analysis is on the differential credibility of major and minor CRAs (section 8). Finally, section 9 draws the conclusions, comparing the reputational damage suffered by the rating industry as a whole and by the various players within it.

\section{Criticisms of Credit Rating Agencies}

With the development of the financial markets, the use of the rating system has become more intense and pervasive and its role has been enriched with new meanings. Alongside its original functions of mitigation of information asymmetry between issuers and investors (Partnoy 1999) and its monitoring of the issuers, the rating has become an important instrument in regulating the financial system and a certification standard (IMF 2010). Over the years, in fact, the supervisory authorities have increased the use of ratings to regulate the conduct of monitored operators (BIS 2009). In particular, in granting to some CRAs the status of National Recognized Statistical Rating Organization (NRSRO) and a higher value for the rating they had provided, the US supervisory authorities have given them the ability to issue a sort of regulatory licence to parties intending to carry out activity on the financial market (Partnoy 2009). Moreover, many other operators have relied on rating reviews to solve the problem of moral hazard: by including them in debt contracts (rating trigger) or by using them to align the behaviour of fund managers to investors' interests or even by controlling access to certain credit lines or to specific markets (Deb-Manning 2011). 
The high penetration of the rating in the financial system has fuelled studies and analyses aimed at determining its actual information quality. The scientific community and the supervisory agencies have focused on this issue, particularly after defaults by major companies or financial crises when CRAs failed to report promptly about these events. Over the years, there have proven to be more and more critical aspects of this industry. In particular, we highlight:

a) The lack of accountability of the entity issuing the rating assessment. Rating agencies claim that ratings are opinions, not a recommendation to invest or disinvest, and, as such, the person who makes the statement cannot be sued for it. (Note 3) For some time, this interpretation of the rating has prevented any sued CRA from accepting liability for damages caused by a rating considered to be too high or too low.

b) The inclusion of ratings in financial legislation. The use of ratings imposed by the supervisory bodies to gain access to certain forms of financing or to assess a company's capital adequacy has created an extremely artificial and rigid demand, mostly concentrated on the few CRAs known as NRSRO. In addition, the establishment of a register, managed for many years with opaque policies, has contributed to an increase in the registered CRAs' bad reputation among investors (2006 Partnoy).

c) The conflict of interest. Most CRAs charge the cost of elaborated ratings to the issuer (White 2001). The issuer-pays model can undermine the reliability of the opinion provided by the agency due to some alignment of views between the parties, at least in the short-term. The issuer has an interest in exerting pressure in order to obtain the highest rating possible, and the agency, in order to retain its customers, can be induced to issue more favourable assessments, lacking independent judgment. On the other hand, the agencies have argued that the need to preserve their own reputation is enough to guarantee the independence and high quality of the information provided. In fact, it is argued that the demand for ratings should be based on a selection mechanism that favours those agencies with a solid reputation of reliability and independence. The conflict of interest implicit in the issuer-pays model would thus be alleviated by the need to preserve the good reputation acquired by the CRA. The subprime mortgage financial crisis undermined the sustainability of this assumption. A good reputation can only function as a deterrent to the conflict of interest as long as there is a sufficient number of issuers of a single agency, with the threat of turning to a competitor, perhaps more compliant, being able to affect its profitability. Alternatively, this system can function well as long as the market is potentially able to punish unreliable agencies. When the customers of a CRA are a small number of large investment banks that continuously feed in over half of their revenue, as occurred when securitised instruments were evaluated, the pressure to issue more favourable ratings is certainly higher (Note 4). In addition, the inclusion of ratings in the financial legislation has reduced the exposure of CRAs to sanctions based on market reputation. The conflict of interest has worsened due to the increasingly widespread practice of providing issuers with additional advisory services besides rating assessments. Consulting services may even go so far as to forecast the possible outcome of the analysis and suggest actions to be undertaken in order to obtain a better assessment (Coffee 2008). In this way, CRAs depend even more upon the activity carried out for a small number of large customers.

d) The monopolistic position of the rating agency with respect to the information used to evaluate the products. This role proved to be meaningful especially in the context of the evaluation of structured products. The complexity and opacity of the instruments in question did not allow the market to verify the reliability of their assessments, possibly drawing from third-party sources, and fuelled many criticisms about the evaluation methodologies used (Linciano 2008).

e) Rating stability. In order to protect the credibility of their own reviews and meet the wishes of investors (Note 5), rating agencies are inclined to attribute the most stable rating possible, with respect to the medium to long-term evolution of the evaluated company. A through-the-cycle process is followed to assess the ability of a company to repay in the event of a recession, even if the current situation is favourable. This strategy explains why CRAs tend to absorb later the changes in the creditworthiness of a company already assessed.

f) Opportunistic behaviour. Rating shopping and unsolicited ratings are the consequences of the issuer-pays compensation model. In the first case, the issuer requests an evaluation of its creditworthiness from several agencies and eventually chooses the one that provides the most positive assessment. In the second case, the CRAs make an unsolicited assessment (which is typically lower than it ought to be as it is only based on public information) and then threaten to make its rating public if the company does not purchase its services. The same opportunistic behaviour may be adopted by a CRA when the issuer decides to instruct a competing agency. 
g) Oligopoly. Despite the ratings market being served by about 150 operators (BIS 2000), the top three agencies hold, now firmly, $96 \%$ of the global market (SEC 2013). Considering the size of their market shares and their stability, it can be said that the Big Three have significant market power and a significant revenue position (Petit 2011). Part of the scientific literature argues that the rating market is naturally led to oligopoly due to the many barriers to entry. The aforementioned public legislation has played an important role in distorting the competitive mechanisms, thus guaranteeing and strengthening the dominant positions already obtained, as well as the role played by the economies of scale, the advantage of experience, and the importance of the reputation acquired. A non-competitive market, with a generally rigid demand, does not offer any incentive to improve or innovate the evaluation methodologies as the reliability of ratings is no longer a priority, replaced instead by the preservation of its own status as a recognised agency. On the other hand, it is not clear whether a rating market open to competition would lead to better quality information. In fact, it is argued that increased competition would reduce the market share of each participant but the resulting compression of future income would reduce incentives to issue quality ratings.

For many years the rating market has thrived in a peculiar situation: CRAs have exercised a complementary function to financial regulation without being subjected to any specific legislation for their activities (Note 6). This privileged status has been gradually removed, particularly due to the crisis in subprime mortgages and the subsequent sovereign debt crisis.

Current European legislation requires all those carrying out professional rating activities to be registered and it entrusts this responsibility to ESMA. The main difference between agencies registered in Europe as External Credit Assessment Institutions (ECAI) and the American qualification of NRSRO lies in the access requirements: those governed by European legislation focus on the professional skills and organisational strength of the applicant, while those subject to the American legislation consider the reputation gained as an important requisite. In the former, there are no barriers for new applicants while, in the latter, well-established agencies are favoured.

The new American legislation devotes a detailed regulation to the prevention and combating of potential conflicts of interest. In fact, it takes into consideration conflict situations that can be rectified through a timely disclosure of their existence, or it applies sanctions to situations with a conflict of interest where, for example, the CRA has a customer that alone produces $10 \%$ or more of its revenue. In addition, actions are contemplated when an issuer is part of the same group as the CRA. The European regulation prevents the conflict of interest through rules of governance for the agencies, for example, by imposing a minimum organisation of the control system inside the CRA and through disclosure regulations on the evaluated subjects. Moreover, it prohibits the agency from offering to the evaluated issuers any consulting service concerning their corporate or legal structure and the management of their capital assets.

In order to enhance the reliability of the rating, both the American and European supervisory authorities adopt requirements of information transparency and operational fairness, prescribing that CRAs make public the assessment methods used and the source of information obtained. In this way, the market should be able to understand and evaluate the quality of the CRAs issuing the assessments.

Both the American and the European legislations deal with the problem of civil liability for the CRAs by placing a limit on the specificity of the exemption scheme. Finally, both authorities take measures to remove from past legislation the many references to ratings that are still present.

\section{Literature Review}

The literature on rating agencies is rich and abundant. Researchers and academicians have been exploring, testing and questioning the role played by these entities in the financial arena since the 1970s. The majority of papers focused on the informative content of ratings and aimed to measure abnormal returns in market prices following various types of announcements made by agencies. In many empirical works, the researchers also took into consideration the abnormal returns preceding rating actions, so as to determine if and to what extent the market anticipates the judgments made by the agencies. In the most recent works, alongside the informative content of rating, their "certification" role is explored. Since many laws and regulations - the most prominent example being the Basel 2 Agreement - have given an official role to rating agencies' valuations, the crossing of certain thresholds affects the behaviour of numerous restricted investors who may be forced to sell a downgraded security or may regain the right to buy an upgraded one (Steiner et Heinke, 2001; Micu et al., 2006; Kiff et al., 2012). In these cases, the abnormal returns are not only - or even not predominantly - a consequence of the information content conveyed by the agency, but they are also a by-product of the gatekeeper status granted by the regulatory framework (Partnoy, 2006). 
Many papers also aimed to distinguish the market impact of rating announcements on the basis of the motivation given by the agency (Goh and Ederington, 1993), the concurrent diffusion of important information by the issuing company (Hand et al., 1992), the presence of a review/outlook anticipating the rating action by the same agency or any preceding announcement by another agency. Studies also differentiate based upon the type of market analysed, the extension of the event windows taken into consideration and the technicalities in the measurement of abnormal returns. Table 1 depicts the state-of-the-art, by summarising the main features and conclusions of the academic literature concerning the informative content of rating announcements, updating and enriching the review made by Norden and Weber (2004).

Starting with the "bad news", negative credit watches - when included by researchers in the sample of events under scrutiny - are almost invariably associated with significant abnormal returns. Since the certification role is, in these cases, less important, the rating agencies seem to convey new information to the markets by their additions to the warning lists. The downgrades are also, in most studies, followed by negative abnormal returns, albeit smaller in magnitude. The evidence is particularly strong when the investment grade threshold is crossed.

Turning to the "good news", the evidence of abnormal returns following positive reviews and upgrades is much weaker. In many papers there is no sign of abnormal returns following upgrades and there is, at best, a limited market impact for positive reviews and outlooks. One reason for this asymmetry is related to the willingness of management to disclose and highlight good news and data. As a consequence, upgrades and positive reviews by rating agencies will normally be anticipated by announcements made by the company and the former will not be able to convey any new information to the market.

Many studies also look at abnormal returns in the weeks or months preceding a rating action. The aim of these empirical tests is to determine whether the rating agencies lead or react to the market. In most cases there is evidence of significant abnormal returns preceding the rating/review change. This "anticipation" does not necessarily exclude a market reaction when a rating action is actually announced, showing that agencies do not merely react to a trend but convey new information or, at least, reinforce and confirm the investors' mood.

Table 1. Summary of the literature concerning the market impact of rating changes

\begin{tabular}{|c|c|c|c|c|c|c|c|c|c|c|}
\hline \multicolumn{2}{|c|}{ Publication details } & \multicolumn{4}{|c|}{ Sample features } & \multicolumn{5}{|c|}{ Conclusions on significant abnormal return } \\
\hline Authors & Year & Market & Period & Obs. & $\begin{array}{l}\text { Event } \\
\text { windows }\end{array}$ & $\begin{array}{l}\text { After negative } \\
\text { reviews }\end{array}$ & $\begin{array}{l}\text { After } \\
\text { downgrade }\end{array}$ & $\begin{array}{l}\text { After } \\
\text { positive } \\
\text { reviews }\end{array}$ & $\begin{array}{l}\text { After } \\
\text { upgrade }\end{array}$ & $\begin{array}{l}\text { Before } \\
\text { rating } \\
\text { actions } \\
\end{array}$ \\
\hline Katz S. & 1974 & Bond & $1966-1972$ & 115 & $\begin{array}{l}{[-12} \\
\text { months; }+5 \\
\text { months] }\end{array}$ & N/A & $\begin{array}{l}\text { Yes, in 6-10 } \\
\text { weeks }\end{array}$ & N/A & $\begin{array}{l}\text { Yes, in } \\
6-10 \text { weeks }\end{array}$ & No \\
\hline $\begin{array}{l}\text { Pinches } \\
\text { G.E., } \\
\text { Singleton } \\
\text { J.C. }\end{array}$ & 1978 & Stock & $1950-1972$ & 207 & $\begin{array}{l}{[-30} \\
\text { months;+12 } \\
\text { months] }\end{array}$ & N/A & No & N/A & No & Yes \\
\hline $\begin{array}{l}\text { Hand J., } \\
\text { Holthause } \\
\mathrm{n} \quad \mathrm{R} . \\
\text { Leftwich } \\
\text { R. }\end{array}$ & 1992 & $\begin{array}{l}\text { Bond and } \\
\text { stock }\end{array}$ & $1977-1983$ & 1.350 & $\begin{array}{l}{[0 ;+1] \text { for the }} \\
\text { stock market. } \\
\text { Closer to } \\
\text { event prices } \\
\text { available for } \\
\text { bond market. }\end{array}$ & $\begin{array}{l}\text { Yes, but only for } \\
\text { additions } \\
\text { classified as } \\
\text { unexpected. }\end{array}$ & $\begin{array}{l}\text { Yes, but only } \\
\text { for } \\
\text { contaminated } \\
\text { announcements } \\
\text {. }\end{array}$ & $\begin{array}{l}\text { Yes, but only } \\
\text { for additions } \\
\text { classified as } \\
\text { unexpected. }\end{array}$ & No & N/A \\
\hline $\begin{array}{l}\text { Goh J.C., } \\
\text { Ederingto } \\
\text { n L.H. }\end{array}$ & 1993 & Stock & 1984-1986 & 482 & $\begin{array}{l}{[-30 ;-11],[-1} \\
0 ;-1],[0 ;+1], \\
{[+2 ;+11],} \\
{[+12 ;+30]}\end{array}$ & $\begin{array}{l}\text { Yes, when the } \\
\text { motivation is } \\
\text { linked to a } \\
\text { deterioration in } \\
\text { firm's financial } \\
\text { prospects. }\end{array}$ & $\begin{array}{l}\text { Yes, when the } \\
\text { motivation is } \\
\text { linked to a } \\
\text { deterioration in } \\
\text { firm's financial } \\
\text { prospects. }\end{array}$ & No & No & $\begin{array}{l}\text { Mixed } \\
\text { evidence. }\end{array}$ \\
\hline
\end{tabular}




\begin{tabular}{|c|c|c|c|c|c|c|c|c|c|c|}
\hline $\begin{array}{l}\text { Richards, } \\
\text { A., } \\
\text { Deddouc } \\
\text { he D. }\end{array}$ & 1999 & Stock & 1998-1999 & 219 & $\begin{array}{l}{[-35 \text { weeks; }} \\
+15 \text { weeks }]\end{array}$ & N/A & No & N/A & $\begin{array}{l}\text { Yes, but } \\
\text { negative } \\
\text { instead of } \\
\text { positive. }\end{array}$ & $\begin{array}{l}\text { Yes, but } \\
\text { only for } \\
\text { downgrades } \\
\text {. }\end{array}$ \\
\hline $\begin{array}{l}\text { Steiner } \\
\text { M., } \\
\text { Heinke V. }\end{array}$ & 2001 & Bond & $1985-1996$ & 728 & {$[-180 ;+180]$} & Yes & $\begin{array}{l}\text { Yes, especially } \\
\text { for downgrades } \\
\text { into } \\
\text { non-investment } \\
\text { grade. }\end{array}$ & No & No & Yes \\
\hline $\begin{array}{l}\text { Gropp R., } \\
\text { Richards } \\
\text { A.J. }\end{array}$ & 2001 & $\begin{array}{l}\text { Bond and } \\
\text { stock }\end{array}$ & $1989-2000$ & 186 & $\begin{array}{l}{[-40 ;-2],} \\
{[-1 ;+1],} \\
{[+2 ;+40]}\end{array}$ & N/A & $\begin{array}{l}\text { Yes, but only in } \\
\text { the stock } \\
\text { market. }\end{array}$ & 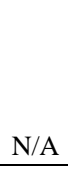 & $\begin{array}{l}\text { Yes, but } \\
\text { only in the } \\
\text { stock } \\
\text { market. }\end{array}$ & No \\
\hline $\begin{array}{l}\text { Schweitz } \\
\text { er R., } \\
\text { Szewczyk } \\
\text { S.H., } \\
\text { Varma R. }\end{array}$ & 2001 & Stock & $1977-1998$ & 92 & {$[+1 ;+2]$} & N/A & Yes & N/A & N/A & N/A \\
\hline $\begin{array}{l}\text { Hull J., } \\
\text { Predescu } \\
\text { M., White } \\
\text { A. }\end{array}$ & 2004 & CDS & $1998-2002$ & 325 & $\begin{array}{l}{[-90 ;-61],} \\
{[-60 ;-31],} \\
{[-30 ;-2],} \\
{[-1 ;+1],} \\
{[+2 ;+10]}\end{array}$ & Yes & No & No & No & Yes \\
\hline $\begin{array}{l}\text { Norden } \\
\text { L., Weber } \\
\text { M. }\end{array}$ & 2004 & $\begin{array}{l}\text { Stock and } \\
\text { CDS }\end{array}$ & 2000-2002 & 397 & $\begin{array}{l}{[-90 ;-61],} \\
{[-60 ;-31],} \\
{[-30 ;-2],} \\
{[-1 ;+1],} \\
{[+2 ;+30],} \\
{[+31 ;+60],} \\
{[+61 ;+90]} \\
\end{array}$ & Yes & Yes & No & No & Yes \\
\hline $\begin{array}{l}\text { Ammer } \\
\text { J., } \\
\text { Clinton } \\
\text { N. }\end{array}$ & 2004 & ABS & $1997-2003$ & 1.292 & $\begin{array}{l}{\left[\begin{array}{ll}-2 & \text { month }\end{array}\right]} \\
{[-1 \text { month }],} \\
{[0 \text { month }]}\end{array}$ & N/A & Yes & N/A & No & $\begin{array}{l}\text { Yes, for } \\
\text { downgrades } \\
\text {. }\end{array}$ \\
\hline $\begin{array}{l}\text { Linciano } \\
\text { N. }\end{array}$ & 2004 & Stock & $1991-2003$ & 299 & $\begin{array}{l}{[-20 ;-11],} \\
{[-10 ;-2],} \\
{[-1 ;+1],} \\
{[+2 ;+10],}\end{array}$ & Yes & Yes & No & $\begin{array}{l}\text { Weak } \\
\text { evidence. }\end{array}$ & $\begin{array}{l}\text { Weak } \\
\text { evidence, } \\
\text { limited to } \\
\text { upgrades/ } \\
\text { downgrades } \\
\text { preceded } \\
\text { by a watch. }\end{array}$ \\
\hline $\begin{array}{l}\text { Micu M., } \\
\text { Remolon } \\
\text { a E., } \\
\text { Woollridg } \\
\text { e P. }\end{array}$ & 2006 & CDS & 2001-2005 & 2.014 & $\begin{array}{l}{[-61 ;-21],} \\
{[-20 ;-1],} \\
{[0 ;+1],} \\
{[+2 ;+20]}\end{array}$ & Yes & Yes & Yes & Yes & Yes \\
\hline $\begin{array}{l}\text { Kiff J., } \\
\text { Nowak } \\
\text { S., } \\
\text { Schumac } \\
\text { her L. }\end{array}$ & 2012 & CDS & $2005-2010$ & 194 & {$[-20 ;+20]$} & Yes & $\begin{array}{l}\text { Yes, but only } \\
\text { for downgrades } \\
\text { out of } \\
\text { investment } \\
\text { grade. }\end{array}$ & Yes & $\begin{array}{l}\text { Yes, but } \\
\text { only for } \\
\text { upgrades } \\
\text { into } \\
\text { investment } \\
\text { grade. }\end{array}$ & $\begin{array}{l}\text { Yes, but } \\
\text { only for } \\
\text { reviews. }\end{array}$ \\
\hline
\end{tabular}


Only a small number of empirical works have focused specifically on banks. From a theoretical point of view, some researchers maintain that rating actions should be able to convey less information to the market when concerning banks, as these financial intermediaries have to comply with enhanced transparency requirements and operate within the framework of strict prudential supervision. The opposite view is expressed by other researchers who highlight that authorities in charge of monitoring banks tend to withdraw bad news, in fear of creating panic among retail investors. If this is the case, rating agencies could disclose information that - even if known to the supervisory authorities - has not been adequately disclosed to the market. In a sense, the authorities' reluctance to pass on bad news could even amplify the effect of a downgrade on market prices.

The empirical evidence on the topic is mixed and does not provide strong support to either of the two theories. Richards and Deddouche (1999) find no significant abnormal stock returns or even a response in the opposite direction - i.e. a price increase following a downgrade - for a sample of emerging market banks. Gropp and Richards (2001) conduct an event study on the impact of rating change announcements on bond and equity prices for a sample of European banks. They find little evidence of announcement effects on bond prices, whereas strong abnormal returns are associated with rating upgrades and downgrades in the stock market during the event window. However, no discernible pre- or post-announcement effect is detected. The divergence of results between equity and debt market is attributed by the authors to the lack of liquidity characterising the latter. Steiner and Heinke (2001) document a smaller price reaction to announcements of watchlisting and rating changes for banks in the framework of a multivariate analysis of the determinants of abnormal returns. Schweitzer et al. (2001) not only find a significant abnormal return when a money centre bank is downgraded, but also document a spillover effect on non-downgraded regional banks.

Our contribution to this line of literature is twofold. Firstly, we include in the sample the rating announcements made by minor rating agencies alongside the major ones, whereas the vast majority of published works only focus on Moody's, Standard \&Poor's and Fitch. The importance of taking into consideration a wider range of CRAs is today reinforced by the regulatory changes underway. Our second contribution is the specific focus on the potential credibility damage suffered by the rating agencies as a consequence of the subprime crisis. To our knowledge, few academic works have specifically explored the issue thus far. Among these few, the work that is most similar to ours is Hun Han et al. (2012) who deal with rating agency reputation and reach the conclusion that the credibility of the major CRAs declined during the 2007-2009 crisis period. However, their approach is different from ours as they do not focus on the abnormal return at the time of a rating change announcement, but on the yield spread related to a given level of rating, comparing major and minor rating agencies on the Japanese bond market.

\section{Sample Description}

The sample consists of 1,609 reviews of ratings issued, in the period 1 November 2003 - 1 November 2013, by the three major CRAs (Standard\&Poor's, Moody's and Fitch) and by four CRAs defined as "minor" in terms of market shares (EJR, R\&I, DBRS and JCR) (Note 7). The issuers we assessed were 106 financial intermediaries $-42 \%$ European, 35\% Asian and 23\% North American - extrapolated from the STOXX 1800 (Note 8) index. The events considered, attributable to the rating on the issuer, include variations downward, upward, confirmations of previous ratings and watchlist entries with positive or negative indications. All data was extracted from the provider Bloomberg.

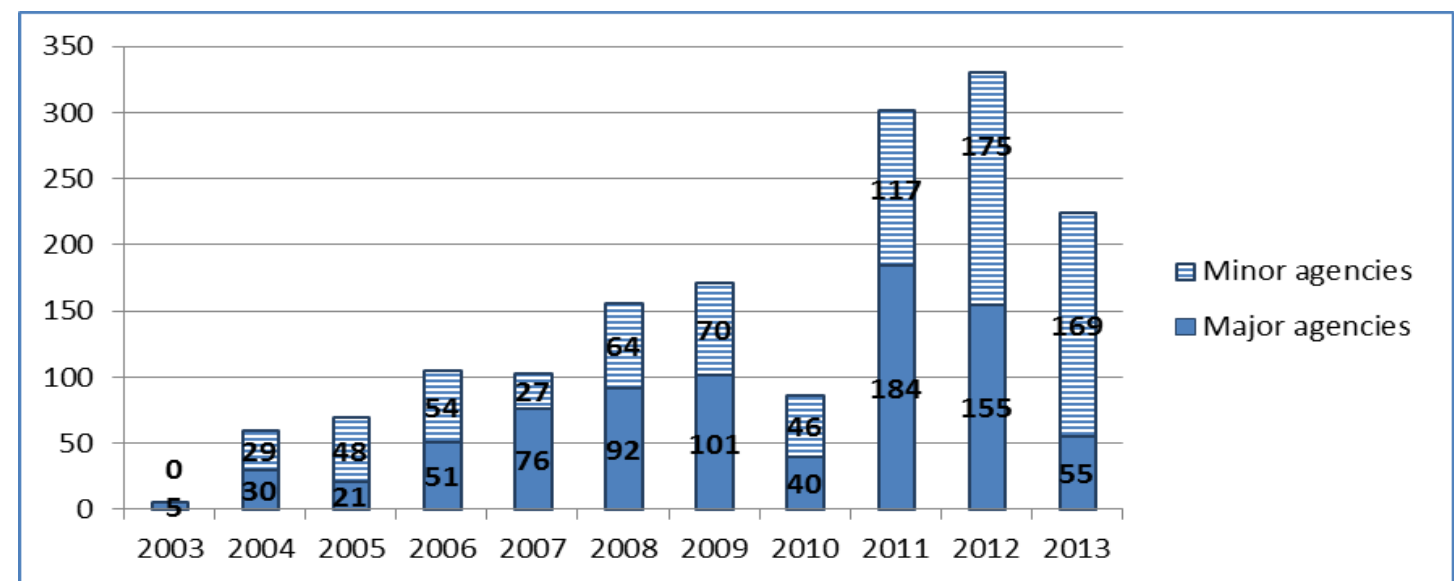

Graph 1. Distribution of rating actions by type of credit rating agency (November 2003 - November 2013)

* The number of reviews of the year 2003 is anomalous because the survey only considers two months, just as, for the year 2013, the events of the final two months are not surveyed. 
The breakdown of the 1,609 rating actions by year (graph 1) and the respective breakdown by the relevant group of CRAs suggest two considerations in relation to the dynamic and composition of the rating actions:

a) The intense informative activity performed by the CRAs, identified by the constant increase of the rating actions until 2009 and by the exponential growth after the significant drop of 2010.

b) The significant role played by the minor agencies, particularly after 2010 .

Over the observed period, each financial intermediary was monitored, on average, by 2.28 agencies; $19 \%$ of the issuers turned exclusively to at least one of the Big Three, $28 \%$ were monitored only by one or more minor agencies while a good 53\% of the issuers obtained the rating from both. Notably, more than half of issuers were subject to evaluation by the two types of CRA commencing from 2011, probably influenced by the guidelines of the ESMA (Note 9).

By reconciling the different alphanumeric characters used by the CRAs to a single numerical scale, which attributes the lowest value to the best credit rating ( $\mathrm{AAA}=1)$ and the highest value to the worst rating $(\mathrm{CCC}=20)$, we can verify how the various agencies have evaluated the issuers over the course of the years (Note 10). The average value of the 1,609 ratings issued, broken down based upon the nature of the agency, indicates that the set of minor CRAs was more severe in its ratings, having totalled an average value higher than that recorded for the larger CRAs. The greater rigour of the minor agencies is constantly clear even when the indicator is processed breaking down the observed time span into three sub-periods: pre-crisis, crisis and post-crisis. The average value of the ratings assigned worsens, as could be expected, moving from the period prior to the bankruptcy of Lehman Brothers to the phase defined as "post-crisis". In addition, in all periods, the average value of the ratings assigned by the major agencies is more benevolent than that processed by their smaller competitors. By breaking down the data, it can be seen that the greater rigour attributed to the set of minor CRAs is largely attributable to the agency EJR which, as is known, is different from its competitors in that it has adopted the "subscriber-pay" model. From the Big Three, the one that issued the most severe ratings was Standard \& Poor's.

Table 2. Average value of outstanding ratings

\begin{tabular}{lccccc}
\hline & no. obs & $\begin{array}{c}\text { average } \\
\text { rating }\end{array}$ & $\begin{array}{c}\text { maximum } \\
\text { value }\end{array}$ & $\begin{array}{c}\text { minimum } \\
\text { value }\end{array}$ & $\begin{array}{c}\text { standard } \\
\text { deviation }\end{array}$ \\
\hline Big & 810 & 5,95 & 1 & 15,25 & 2,53 \\
\hline NoBig & 799 & 6,55 & 2 & 20 & 2,79 \\
\hline Total observations & 1609 & & & & \\
\hline Breakdown of reviews of ratings by periods & & & & \\
\hline Pre-crisis Big & 222 & 4,38 & 1 & 10 & 1,73 \\
\hline Pre-crisis NoBig & 181 & 4,69 & 2 & 10 & 1,61 \\
\hline Crisis Big & 142 & 4,99 & 2 & 11 & 1,49 \\
\hline Crisis NoBig & 88 & 5,33 & 2,75 & 9 & 1,47 \\
\hline Post-crisis Big & 437 & 7,05 & 1,25 & 15,25 & 2,60 \\
\hline Post-crisis NoBig & 525 & 7,38 & 2 & 20 & 2,90 \\
\hline Breakdown of reviews of ratings by Agency & 180 & 4,98 & 2 & 13 & 2,09 \\
\hline DBRS & 230 & 5,23 & 1 & 14 & 2,59 \\
\hline Moody's & 249 & 5,35 & 3 & 10 & 1,36 \\
\hline R\&I & 32 & 5,59 & 2 & 9 & 2,07 \\
\hline JCR & 217 & 5,74 & 2 & 11 & 1,98 \\
\hline Fitch & 354 & $\mathbf{6 , 5 4}$ & 2 & 15,25 & 2,65 \\
\hline S\&P & 333 & $\mathbf{8 , 3 8}$ & 3 & 20 & 2,91 \\
\hline EJR & & & & &
\end{tabular}




\begin{tabular}{lcc}
\hline & $\begin{array}{c}\text { Mean difference in rating } \\
\text { valuations }\end{array}$ & T-stat \\
\hline Big-NoBig - All periods & $-0,6$ & $-4,52^{* * *}$ \\
\hline Big-NoBig - Pre-crisis period & $-0,31$ & $-1,86^{* *}$ \\
\hline Big-NoBig - Crisis period & $-0,34$ & $-1,69^{* *}$ \\
\hline Big-NoBig - Post-crisis period & $-0,33$ & $-1,86^{* *}$ \\
\hline EJR-NoBig & 1,00 & $4,91^{* * *}$ \\
\hline
\end{tabular}

When restricting the analysis on the "severity" to only 57 issuers evaluated both by the major and minor CRAs, this confirms what has previously been stated (Table 3 ). In $72 \%$ of cases the rating assigned by the minor CRAs was found to be on average lower by 2 notches compared to that issued by the Big Three. The evaluation difference between major and minor CRAs, more significant in the post-crisis period, justifies the decision to analyse the two samples separately, so as to verify if the loss of credibility involved all the CRAs or only the bigger ones.

Table 3. Rating severity

\begin{tabular}{llll}
\hline & $\mathbf{2 0 0 4 - 2 0 1 3}$ & $\mathbf{2 0 1 0 - 2 0 1 3}$ & $\mathbf{2 0 0 4 - 2 0 0 9}$ \\
\hline \% greater severity CRAs NoBig & $72 \%$ & $56 \%$ & $34 \%$ \\
\hline no. issuers & 57 & 52 & 38 \\
\hline Average rating CRAs Big & 5,05 & 6,00 & 3,37 \\
\hline Equivalent to & $\mathrm{A}+$ & $\mathrm{A}$ & $\mathrm{AA} *_{-}$ \\
\hline Average rating CRAs NoBig & 7,17 & 9,05 & 3,97 \\
\hline Equivalent to & $\mathrm{A}-$ & $\mathrm{BBB}$ & $\mathrm{AA}-$ \\
\hline Difference & 2,13 & 3,05 & 0,61 \\
\hline Tstat & $4,28 * * *$ & $5,37 * * *$ & 0,14 \\
\hline
\end{tabular}

In examining the composition of the sample by type of reviews (Table 4), the downgrades by the major agencies prevail, both during the crisis and in later years. In 19 cases of downgrading, this caused the transfer of the issuer from the investment grade category to the speculative category, while among the upgrades, the advancement of category occurred in 7 cases. The peculiarity of the samples of rating actions issued by the minor agencies lies in the strong presence of ratings that confirm the one assigned. These are 392 rating actions, expressed by the minor agencies R\&I and EJR, and indicated as "Stable". It would appear that the agencies in question are likely to be more severe and "firm" in their ratings. The greater stability of the assigned rating is also supported by a more contained number of credit watches issued by the minor CRAs, compared to those indicated by the Big Three.

Table 4. Reviews of ratings by type

\begin{tabular}{lllllllllllll}
\hline & Down & Up & Stable & Watch & Down & Up & Stable & Watch & Down & Up & Stable & Watch \\
\hline Big & 58 & 140 & - & 48 & 126 & 16 & - & 45 & 380 & 50 & - & 166 \\
\hline NoBig & 15 & 56 & 75 & 20 & 46 & 6 & 30 & 27 & 119 & 33 & 287 & 21 \\
\hline & Pre-crisis & & & Crisis & & & Post-crisis & & \\
\hline
\end{tabular}

Table 5 highlights the rating borders, included between the values 8.25 (BBB+ with negative watch) and 10.75 (BBwith positive watch), which may, due to a subsequent rating action, lead to the transfer of the issuer from the investment category to the speculative category and vice versa. The highest number of rating borders is that 
formulated by the Big Three during the post-crisis period. Their average value, however, is slightly better than that calculated for the rating borders of the smaller CRAs.

Table 5. Rating border

\begin{tabular}{llllll}
\hline \multicolumn{2}{l}{ Number of rating border } & & & \multicolumn{2}{l}{ Average value of rating border } \\
\hline & Big & Non Big & Total & Big & Non Big \\
\hline Pre-crisis & 10 & 7 & $\mathbf{1 7}$ & 9,00 & 9,20 \\
\hline Crisis & 4 & 1 & $\mathbf{5}$ & 8,31 & 8,25 \\
\hline Post-crisis & 89 & 68 & $\mathbf{1 5 7}$ & 8,74 & 9,13 \\
\hline Total & 103 & 76 & $\mathbf{1 7 9}$ & 8,74 & 9,12 \\
\hline
\end{tabular}

Finally, Table 6 identifies the incidence of cases (40\%) in which a rating event has led to a market reaction contrary to expectations (appreciation of the stock against a downgrading or depreciation of the stock following an upgrading). The high number of "contrarians" is at the basis of the decision to conduct our analyses on the reliability of the CRAs considering the absolute value of the abnormal returns achieved.

Table 6. Ratings with contrarian effect

\begin{tabular}{cccc}
\hline & No. observations & N. contrarian & Contrarian incidence \\
\hline Pre-crisis & 408 & 176 & $43,14 \%$ \\
\hline Crisis & 233 & 112 & $48,07 \%$ \\
\hline Post-crisis & 968 & 352 & $36,36 \%$ \\
\hline Total & 1609 & 640 & $39,78 \%$ \\
\hline
\end{tabular}

\section{The Methodology}

In order to evaluate the reputational damage suffered by credit rating agencies, we adopt a standard event study methodology. We measure the abnormal return for each rating action included in our sample in a 3-day event window centred on the announcement day $[-1 ; 1]$. The inclusion of the day before the rating action is motivated by the potential spillover of information preceding the formal communication, whereas the day after is included as we do not know the precise timing of the announcement, which can even take place during the evening when trading is closed. Such a short event window is in line with our research question, focused on the reputation of rating agencies and the informative value of their actions. The price drift in the following days and weeks may be the result of autonomous analysis performed by investors, even if stimulated by the rating change, whereas the immediate return is more strictly dependent on the level of faith placed in the expertise of the agency.

We calculate the cumulated abnormal return as follows:

$$
C A R_{t ; i}=r_{t ; i}-\propto_{t ; i}-\beta_{t ; i} \times r_{t ; m}
$$

where:

$C A R_{t ; i} \quad$ Cumulative abnormal stock price return for company $i$ in the 3-day event window centred on a rating action announced at time $t$.

$r_{t ; i} \quad$ Daily stock price return of company $i$.

$\alpha_{t ; i} \quad$ Intercept of the regression line between the daily stock price returns of company $i$ and the daily returns of the Stoxx 1800 Banks Index, calculated over a moving estimation window of 500 days.

$\beta_{t ; i} \quad$ Slope of the regression line between the daily stock price returns of company $i$ and the daily returns of the Stoxx 1800 Banks Index, calculated over a moving window of 500 days.

$r_{t ; m} \quad$ Daily return of the Stoxx 1800 Banks Index. 
As we are specifically interested in the informative content of rating actions and thus in the magnitude of the price reactions to the announcement by the agencies, independently from its sign, we focus on the absolute value of cumulative abnormal return, adopting an approach similar to Grothe (2013):

$$
A B S_{-} C A R_{i ; t}=\left|C A R_{i ; t}\right|
$$

The nature of the dependent variable, expressed in absolute value, is one of the peculiarities of our work compared to mainstream literature. The reason for this methodological choice is related to our focus on the equity market impact of rating actions. There is strong empirical evidence (Goh and Ederington, 2003) to support that the impact of a downgrading (upgrading) is not always negative (positive) on equity prices, as would be the case in the bond market. The sign of the impact very much depends on the kind of motivation given by the rating agency for the downgrading (upgrading). In particular, when the downgrading is related to an increase in leverage - which entails a redistribution of wealth between bondholders and shareholders - the impact on equity prices tends to be positive. As a consequence, even if we were to subdivide the entire sample into downgradings and upgradings, this would reveal a very mixed situation in terms of CAR signs and the coefficients of the parameters would be impossible to interpret. The evidence on the phenomenon specifically concerning our sample was examined in Table 6.

We establish the beginning of the crisis at 15 September 2008: the day on which the default of Lehman Brothers was announced to the market. This choice was motivated by the fact that that day marks the beginning of the crisis for the large audience of investors, i.e. the moment when the subprime crisis stopped being a threat known by a restricted pool of professionals and transformed into widespread turmoil. In order to identify the end of the crisis, we consider the moment when the level of the VIX Index returned below the mean level calculated in the month before Lehman's bankruptcy. The VIX - also known as "fear index" - is particularly suitable for representing the level of tension in the stock market. The end of the crisis period, using the described criteria, is established at 15 October 2009. Thus, the two periods are defined as follows: pre-crisis and crisis (1 November 2003 - 15 October 2009); post-crisis (15 October 2009 - 1 November 2013). Our main focus of interest is the post-crisis period. In fact, we aim to understand if investors changed their attitude towards rating actions after discovering their weaknesses during the crisis. The change in attitude can be better judged in a market context that has returned to normality.

We then perform a multivariate econometric analysis of the 3-day cumulative abnormal returns associated with rating actions using the OLS method. As independent variables, we consider a set of standard factors that have proved to be relevant in past empirical works. In particular, we consider the extent of the rating change, measured in notches. To this end, we translate the alphanumerical rating scale of each agency into a numerical scale made up of fourteen levels, where the highest ranking (AAA or similar) is equal to 1 and the lowest is equal to 20 . The credit watch is translated into a quarter of a notch i.e. +0.25 in the case of a negative watch and -0.25 in the case of a positive watch. We expect the absolute value of the change of notches to be positively related to the dependent variable.

We then consider the potential impact of the certification role played by agencies whereby a change in rating above or below the speculative level exerts pressure on numerous restricted investors. We create a dummy variable BORDER which is equal to 1 when either the last available rating or the new announced rating is near the threshold between speculative and investment grade (i.e. it is equal to BBB or BB) and, otherwise, it is 0 . We expect the variable to be positively related to the dependent variable. In fact, the market is likely to react more intensely, both to positive and negative news, when the company is on the verge of a critical level.

We also introduce a dummy variable, CONTAMIN, which is equal to 1 if there is evidence of another announcement, by the same or by another rating agency, in the 30 preceding days, and a dummy ANTICIP, which is equal to 1 when the downgrading or upgrading has been anticipated by a credit watch. We expect a negative coefficient for both variables, since the informative content of the announcement has - in both cases - already been conveyed to the investors and probably discounted by market prices.

We introduce a dummy CREDIT_WATCH to distinguish actual rating changes from inclusions in the warning list that can precede a downgrade or an upgrade. We expect a greater market impact for credit warnings, in line with the empirical evidence that has emerged from the literature.

We also introduce a variable accounting for the distance between a new evaluation issued by an agency and the average outstanding ratings on the company during the same year. In particular, the GAP_RAT variable is equal to 1 when the new judgment is more than one notch away from the average ratings received by the company in same year. We expect a positive coefficient for this dummy, since the market should react more intensely to opinions that are far away from the consensus. 
We consider - as control factors - the level of VIX Index and the standard deviation of the specific stock affected by the rating action in the 50 preceding working days. We expect a positive coefficient for both variables, assuming that a more volatile and nervous market or security will react more intensely to any kind of news.

Finally - and this is the core of our analysis - we consider a temporal dummy variable: POST_CRISIS the value of which is equal to 1 for all dates after 15 October 2009 and 0 elsewhere. This dummy is the main instrument we use to gauge the reputational impact of the subprime crisis on rating agencies. We forecast a negative coefficient for the POSTCRISIS variable. In particular, we expect the phenomenon to manifest itself more strongly when the regulatory and psychological threshold of the junk level is distant. To test this aspect, in some specifications we substitute the dummy POST_CRISIS with two dummies: the BORDER_POSTCRISIS variable which is equal to one when a rating action is in the post-crisis period and concerns a company close to the threshold between speculative and investment grade; the NOBORDER_POSTCRISIS variable which is equal to 1 when the action takes place during the post-crisis period and concerns a company whose evaluation is distant from the critical threshold. We expect a higher and more significant negative coefficient for the second dummy variable. In fact, in the former case, the market return is influenced by regulatory-induced trading, independently from the real trust in the information conveyed by the announcement.

The same set of variables was tested, separately, on both the subsamples of rating actions issued by the three major and the four minor CRAs. Finally, the two subsamples were merged in order to test - through a dummy variable labelled BIG - if the market reaction to the announcements made by the Moody's, Standard \& Poor's and Fitch is lower than the impact generated by the announcements by the minor agencies. We expect this to be the case in the post-crisis period. Thus, the expected coefficient for the dummy BIG is negative. We also tested - through the variable EJR - if the market reacts more intensely to the only credit rating agency characterised by an investor-pay model as opposed to the standard issuer-pays model. Since the lower exposure to conflict of interests should maximise investors' trust, we expect a positive coefficient for this dummy variable. Finally, we also tested - through the variable $\mathrm{S} \& \mathrm{P}$ - if the market reacts more to the agency, among the majors, which emerged as more severe in its valuations during the descriptive analysis of the database.

Table 7 summarises the independent variables used in the econometric analysis and their expected coefficients.

Table 8 is a matrix of the correlations between our independent variables. The values in bold type signal the variables which are highly correlated and cannot be included together in the specifications. In particular, the two measures of volatility - market-wide and security-specific - are highly correlated, so we use them alternatively so as to perform a robustness check of our results. The dummy STABLE is highly correlated with both the regressors DOWN, WATCH. For this reason in the analysis presented in section 7, the dummy STABLE will be used to delimitate a subsample, instead of including it in the specifications.

Table 7. Independent variables included in the econometric analysis - Definition and expected sign of the coefficient

\begin{tabular}{|c|c|c|}
\hline Name & Definition & Expected sign \\
\hline VA_CHGNOT & $\begin{array}{l}\text { Absolute value of the change in rating level, calculated } \\
\text { on the basis of a numerical conversion of the } \\
\text { alphanumerical scale used by CRAs, where the highest } \\
\text { rating is equal to } 1 \text { and the lowest is equal to } 14 \text {. The } \\
\text { positive and negative watches are equal to }-0.25 \text { and } \\
+0.25 \text { respectively. }\end{array}$ & + \\
\hline DOWN & $\begin{array}{l}\text { Dummy variable which is equal to } 1 \text { when the rating } \\
\text { announcement worsens the credit valuation of an issuer. }\end{array}$ & + \\
\hline STABLE & $\begin{array}{l}\text { Dummy variable which is equal to } 1 \text { when the rating } \\
\text { announcement leaves the previous valuation on the issuer } \\
\text { unchanged. }\end{array}$ & - \\
\hline CONTAMIN & $\begin{array}{l}\text { Dummy variable which is equal to } 1 \text { if the distance } \\
\text { between two subsequent rating announcements on the } \\
\text { same company is less than } 30 \text { days, provided the two } \\
\text { actions are in the same direction (i.e. both upgrades and } \\
\text { downgrades). }\end{array}$ & + \\
\hline ANTICIP & Dummy variable which is equal to 1 when a & - \\
\hline
\end{tabular}




\begin{tabular}{|c|c|c|}
\hline & $\begin{array}{l}\text { downgrading or upgrading are preceded by a watch in the } \\
\text { same direction (i.e. a negative watch for the } \\
\text { downgradings and a positive watch for the upgradings). }\end{array}$ & \\
\hline CONTRARIAN & $\begin{array}{l}\text { Dummy variable which is equal to } 1 \text { when the return } \\
\text { following a rating action has a counterintuitive sign (i.e. } \\
\text { a positive return following a downgrading or a negative } \\
\text { return following an upgrading) }\end{array}$ & - \\
\hline GAP_RAT & $\begin{array}{l}\text { Dummy variable which is equal to } 1 \text { when the new rating } \\
\text { assigned is more than one notch away from the average } \\
\text { of outstanding ratings on the issuer in the same year }\end{array}$ & + \\
\hline BORDER & $\begin{array}{l}\text { Dummy variable which is equal to } 1 \text { if the last or current } \\
\text { ratings are between } \mathrm{BBB}+\text { and } \mathrm{BB} \text { - and } 0 \text { otherwise. }\end{array}$ & + \\
\hline WATCH & $\begin{array}{l}\text { Dummy variable which is equal to } 1 \text { if the announcement } \\
\text { consists of a credit warning rather than a downgrading or } \\
\text { upgrading. }\end{array}$ & + \\
\hline VIX & $\begin{array}{l}\text { Value of the VIX index on the day of the announcement } \\
\text { of the rating action. }\end{array}$ & + \\
\hline DEVST & $\begin{array}{l}\text { Standard deviation of the daily returns in the } 50 \text { working } \\
\text { days preceding the rating action for the specific stock } \\
\text { affected by the announcement. }\end{array}$ & + \\
\hline POSTCRISIS & $\begin{array}{l}\text { Dummy variable which is equal to } 1 \text { for all } \\
\text { announcements after } 15 \text { October } 2009 .\end{array}$ & + \\
\hline NOBORDER_POSTCRISIS & $\begin{array}{l}\text { Dummy variable which is equal to } 1 \text { when the } \\
\text { announcement is in the post-crisis period and concerns } \\
\text { an issuer that is not on the verge of the critical threshold } \\
\text { between investment and junk grade. }\end{array}$ & - \\
\hline BORDER_POSTCRISIS & $\begin{array}{l}\text { Dummy variable that is equal to } 1 \text { when the } \\
\text { announcement is in the post-crisis period and concerns } \\
\text { an issuer that is on the verge of the critical threshold } \\
\text { between investment and junk grade. }\end{array}$ & - \\
\hline BIG & $\begin{array}{l}\text { Dummy variable that is equal to } 1 \text { when the rating } \\
\text { announcement is made by Moody's, Standard and Poor's } \\
\text { or Fitch }\end{array}$ & - \\
\hline ANTICIP_BIG & $\begin{array}{l}\text { Dummy variable that is equal to } 1 \text { when a rating } \\
\text { announcement made by a minor CRA follows an } \\
\text { announcement made by a major CRA in the last } 50 \text { days }\end{array}$ & - \\
\hline EJR & $\begin{array}{l}\text { Dummy variable which is equal to } 1 \text { when the rating } \\
\text { action has been announced by the agency EJR. }\end{array}$ & + \\
\hline
\end{tabular}


Table 8. Correlation matrix - main independent variables

\begin{tabular}{|c|c|c|c|c|c|c|c|}
\hline 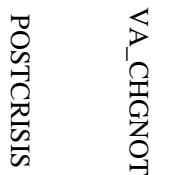 & $\begin{array}{l}\text { o } \\
z \\
\text { z } \\
\text { z } \\
\text { z }\end{array}$ & 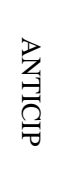 & $\begin{array}{l}\text { ¿ } \\
\text { zo }\end{array}$ & $\frac{n}{\mathbb{H}}$ & $\begin{array}{l}\underset{Z}{D} \\
\stackrel{\Omega}{\Omega}\end{array}$ & 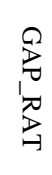 & $\grave{x}$ \\
\hline
\end{tabular}

\begin{tabular}{|c|c|c|c|c|c|c|c|c|c|c|c|c|c|}
\hline POSTCRISIS & 1,0000 & $-0,0083$ & 0,0056 & $-0,0434$ & 0,0926 & 0,1658 & $-0,0315$ & 0,0841 & $-0,3232$ & $-0,2730$ & $-0,1025$ & 0,0014 & 0,3788 \\
\hline VA_CHGNOT & $-0,0083$ & 1,0000 & 0,1577 & 0,3460 & 0,4640 & $-0,6037$ & $-0,1539$ & 0,4029 & 0,0331 & 0,1283 & 0,3499 & $-0,0667$ & $-0,1483$ \\
\hline CONTAMIN & 0,0056 & 0,1577 & 1,0000 & 0,0795 & 0,2276 & $-0,1956$ & 0,1525 & 0,0696 & 0,1303 & 0,1868 & 0,2462 & $-0,0700$ & $-0,1449$ \\
\hline ANTICIP & $-0,0434$ & 0,3460 & 0,0795 & 1,0000 & 0,2989 & $-0,2842$ & $-0,1358$ & 0,0414 & 0,0050 & 0,1423 & 0,2937 & $-0,0649$ & $-0,2351$ \\
\hline DOWN & 0,0926 & 0,4640 & 0,2276 & 0,2989 & 1,0000 & $-0,6693$ & 0,3834 & 0,1816 & 0,3147 & 0,4020 & 0,4944 & $-0,0291$ & $-0,2918$ \\
\hline STABLE & 0,1658 & $-0,6037$ & $-0,1956$ & $-0,2842$ & $-0,6693$ & 1,0000 & $-0,3053$ & $-0,2497$ & $-0,1468$ & $-0,2503$ & $-0,6593$ & 0,0997 & $\mathbf{0 , 4 5 3 1}$ \\
\hline WATCH & $-0,0315$ & $-0,1539$ & 0,1525 & $-0,1358$ & 0,3834 & $-0,3053$ & 1,0000 & $-0,1074$ & 0,1347 & 0,1714 & 0,2911 & $-0,0239$ & $-0,2755$ \\
\hline GAP_RAT & 0,0841 & 0,4029 & 0,0696 & 0,0414 & 0,1816 & $-0,2497$ & $-0,1074$ & 1,0000 & $-0,0426$ & 0,0835 & 0,1096 & 0,0652 & 0,0576 \\
\hline VIX & $-0,3232$ & 0,0331 & 0,1303 & 0,0050 & 0,3147 & $-0,1468$ & 0,1347 & $-0,0426$ & 1,0000 & 0,6892 & 0,1270 & 0,0108 & $-0,2119$ \\
\hline DEVST & $-0,2730$ & 0,1283 & 0,1868 & 0,1423 & 0,4020 & $-0,2503$ & 0,1714 & 0,0835 & 0,6892 & 1,0000 & 0,1885 & 0,0640 & $-0,1907$ \\
\hline BIG & $-0,1025$ & 0,3499 & 0,2462 & 0,2937 & 0,4944 & $-0,6593$ & 0,2911 & 0,1096 & 0,1270 & 0,1885 & 1,0000 & $-0,2522$ & $-0,5453$ \\
\hline ANTICIP_BIG & 0,0014 & $-0,0667$ & $-0,0700$ & $-0,0649$ & $-0,0291$ & 0,0997 & $-0,0239$ & 0,0652 & 0,0108 & 0,0640 & $-0,2522$ & 1,0000 & 0,1586 \\
\hline EJR & 0,3788 & $-0,1483$ & $-0,1449$ & $-0,2351$ & $-0,2918$ & 0,4531 & $-0,2755$ & 0,0576 & $-0,2119$ & $-0,1907$ & $-0,5453$ & 0,1586 & 1,0000 \\
\hline
\end{tabular}

\section{Analysis of the CARs for the Rating Actions Announced by Moody's, S\&Ps and Fitch}

As already explained above, we start the analysis from the sub-sample of rating actions announced by the three major agencies - Moody's, Standard \& Poor's and Fitch - which had a more direct involvement in the subprime scandal and which may have suffered the greater reputational damage.

We perform a multivariate econometric analysis with the OLS method, using ABS_CAR as a dependent variable and the regressors defined in Table 7. The first two specifications in Table 9 are minimal and include the temporal dummy alongside the two alternative measures of volatility: market-wide and security-specific. In these cases, the entire set of 810 observations is included, since we do not have missing data. The abnormal return is positively related to the level of volatility, both at market-wide and security-specific level. The DUMMY_POSTCRISIS displays the expected negative sign and the coefficient is significant at the $5 \%$ confidence level when the VIX is used to account for market volatility, while the significance increases further when considering the security-specific standard deviation. The total explicative power, measured by the adjusted R-squared, is around 20 per cent.

The third specification details the results of an analysis where the set of independent variables is enriched, at the cost of reducing the set of events to 716 . The new factors introduced control for the type of rating action, the time passing from a previous intervention by another or the same agency, the intensity of the rating change measured in notches and the anticipation of a downgrade or upgrade by a previous credit watch. The regression also includes 3 dummies corresponding to the outliers identified in the distribution. Although all factors present the expected sign, their statistical significance is low and the increase in the R-squared - which reaches the level of 46 per cent - can be attributed almost exclusively to the outliers' management.

In the fourth specification, we substitute the DUMMY_POSTCRISIS with two factors that allow us to distinguish in the post-crisis period - the effect of rating actions near to the borderline between the speculative and investment 
grade from those concerning companies in a "safe zone". The lack of trust should manifest more strongly when there is less regulation-induced trading. The results show that the absolute value of abnormal return is lower, in the post-crisis period, when the rating is distant from the critical threshold. Conversely, there is no significant under-reaction in the post-crisis period when the current rating or the last available rating is near to the borderline between junk and investment grade. In this case, in fact, all restricted investors are induced to react, independently from their trust in the rating agency's announcement.

Column (5) focuses on downgradings that are, in literature, often associated with a greater informative content for market participants. There are 552 available observations. The evidence is in line with the other specifications. In particular, the negative and significant coefficient of the POSTCRISIS dummy is confirmed.

Finally, in column (6) we exclude from the sample all rating announcements made during the bulk of the crisis period (i.e. from 15 September 2008 to 15 October 2009). The reason for the exclusion is that - during this very peculiar period - the market could well have displayed very unusual behaviour. Furthermore, by thus restricting the sample, we can carry out a direct comparison between the post-crisis and pre-crisis period, without the disturbance effect of the strong volatility characterising the year 2009. The evidence confirms that, after the crisis, the market reacts to the announcements by major CRAs less strongly than it used to. Looking at the other significant explicative variables, the abnormal stock return is positively related to the security-specific volatility, it is higher when the announcement is a watch-listing instead of a downgrade or upgrade and it is lower when the stock return has a counter-intuitive sign, i.e. a positive return following a downgrading or a negative return following an upgrading.

We can conclude that the major rating agencies have indeed suffered reputational damage as a consequence of the subprime crisis which translates into a weaker market reaction to their announcements. This is particularly evident when the crossing of a regulatory threshold is not involved and, thus, when there is less market impact from restricted investors who are obliged to react independently from their trust in the informative content conveyed by the agency.

Table 9. Determinants of the ABS_CAR - Major rating agencies

The regressions are all conducted with the ordinary least square method. The dependent variable is ABS_CAR i.e. the absolute value of cumulative abnormal return calculated as defined in section 5 . The independent variables are described in Table 7.

The t-stat are reported in brackets under each coefficient. White heteroskedasticity-consistent standard errors and covariance. The specifications (3) and (4) have been calculated including three dummies corresponding to the outliers identified in the distribution.

$*$ = significant at $10 \%$ level; $* *=$ significant at $5 \%$ level; $* * *=$ significant at $1 \%$ level with a two-tailed test.

\begin{tabular}{|c|c|c|c|c|c|c|}
\hline & (1) & (2) & (3) & (4) & $(5)$ & (6) \\
\hline Subsample & - & - & - & - & Downgradings & $\begin{array}{c}\text { Pre-crisis + } \\
\text { Post-crisis } \\
\end{array}$ \\
\hline VA_CHGNOT & & & $\begin{array}{c}0,27 \\
(0,84) \\
\end{array}$ & & $\begin{array}{c}0,32 \\
(0,79) \\
\end{array}$ & $\begin{array}{c}0,, 52 * * \\
(2,15) \\
\end{array}$ \\
\hline CONTAMIN & & & $\begin{array}{c}-0,43 \\
(-1,13) \\
\end{array}$ & $\begin{array}{c}-0,14 \\
(-0,35) \\
\end{array}$ & $\begin{array}{c}-0,07 \\
(-0,17) \\
\end{array}$ & $\begin{array}{c}-0,24 \\
(-0,44) \\
\end{array}$ \\
\hline DUMMY_ANTICIP & & & $\begin{array}{c}-0,53 \\
(-1,40)\end{array}$ & & $\begin{array}{l}-0,09 \\
(0,19) \\
\end{array}$ & $\begin{array}{c}-0,18 \\
(-0,65) \\
\end{array}$ \\
\hline RATING_BORDER & & & $\begin{array}{c}0,38 \\
(0,78)\end{array}$ & & $\begin{array}{c}0,88 \\
(1,51)\end{array}$ & \\
\hline CONTRARIAN & & & & & & $\begin{array}{c}-0,18 * * * \\
(-3,63)\end{array}$ \\
\hline GAP_RAT & & & $\begin{array}{c}0,55 \\
(1,62) \\
\end{array}$ & $\begin{array}{c}0,84 * * \\
(2,42) \\
\end{array}$ & $\begin{array}{c}1,04 * * \\
(2,51)\end{array}$ & $\begin{array}{c}0,29 \\
(1,12)\end{array}$ \\
\hline DUMMY_POSTCRISIS & $\begin{array}{l}-0,62 * * \\
(-2,23)\end{array}$ & $\begin{array}{c}-0,96 * * * \\
(-3,09)\end{array}$ & $\begin{array}{c}-1,11 * * * \\
(-3,26)\end{array}$ & & $\begin{array}{c}-2,13 * * * \\
(-4,14)\end{array}$ & $\begin{array}{c}-0,71 * * \\
(-1,97)\end{array}$ \\
\hline
\end{tabular}




\begin{tabular}{|c|c|c|c|c|c|c|}
\hline NOBORDER_POSTCRISIS & & & & $\begin{array}{c}-1,19 * * * * \\
(-3,72)\end{array}$ & & \\
\hline BORDER_POSTCRISIS & & & & $\begin{array}{c}0,11 \\
(0,26)\end{array}$ & & \\
\hline VIX & $\begin{array}{c}0,19 * * * \\
(6,73)\end{array}$ & & & $\begin{array}{c}0,15^{* * * *} \\
(7,22)\end{array}$ & $\begin{array}{c}0,12^{* * * *} \\
(6,17)\end{array}$ & \\
\hline DEVST & & $\begin{array}{c}0,90^{* * * *} \\
(\mathbf{7 , 6 9 )}\end{array}$ & $\begin{array}{c}0,77 * * * \\
(12,66)\end{array}$ & & & $\begin{array}{c}0,66^{* * * *} \\
(6,53)\end{array}$ \\
\hline DUMMY_WATCH & & & $\begin{array}{c}0,57 \\
(1,49)\end{array}$ & $\begin{array}{l}0,63^{*} \\
(1,72)\end{array}$ & & $\begin{array}{c}0,96 * * * \\
(3,04)\end{array}$ \\
\hline Adjusted R2 & 0,192 & 0,212 & 0,462 & 0,436 & 0,276 & 0,123 \\
\hline No. observations & 810 & 810 & 716 & 716 & 552 & 578 \\
\hline
\end{tabular}

\section{Analysis of the CARs for the Rating Actions Announced by the Minor CRAs}

We conducted the analysis on the rating sample made up of the minor agencies - EJR, DBRS, JCR and R\&I - testing the same independent variables used for the sample of the Big Three, in order to check if the effects are similar or if there are discrepancies (Table 10). The first set of regressors (1) presents the sign of coefficients in line with expectations: in the post-crisis the market reacts less compared to the past, with a significant coefficient at $5 \%$ when the VIX is used to consider market volatility. The total explicative power, measured by the adjusted R-squared, is below 20 per cent. In the second scenario, adding the dummy WATCH, the sign of the DUMMY_POSTCRISIS remains unchanged but loses significance; the presence of a watch issued by the minor agencies causes greater market reactions, with a significant coefficient at $5 \%$. However, the statistical relevance of the indicated factors is contained and the increase of the R-squared (57 per cent) is determined mainly by the dummies correspondent to the outliers identified in the distribution.

By enriching the study with other variables, such as the combination between rating in the critical area and in the post-crisis period, the presence of a downgrading, any anticipation of the rating by a major agency and the fact that the rating has been formulated by the agency EJR, the sample of events is reduced, but the weight of the factors that validate our theory is increased (3). It was not possible to include, in the analysis of this sample, the interaction between DUMMY BORDER and DUMMY POSTCRISIS due to the high correlation with the regressor EJR. As a result of the subprime mortgage crisis, also in relation to ratings expressed by minor agencies, the market reacts less, albeit with more contained intensity compared to what is observed for their major competitors. The negative and significant coefficient for the border issuers, in contrast with what is found in the ratings issued by the more important CRAs, could be explained by the limited use, for certification, of ratings issued by the smaller agencies. When the rating is anticipated by the Big CRAs, the market reacts less, but the coefficient is not significant. It is interesting to note that the absolute value of the abnormal return is higher when the rating action is formulated by EJR, the only agency that adopts "subscriber-pay" remuneration.

Given that in the sample of rating actions issued by the minor agencies, more than half of the announcements issued confirm the previous rating and they do not, therefore, add new information, we decided to repeat the analysis restricting the sample only to events that involved a rating change (4). The new combination of independent variables is able to explain a higher value of abnormal return (R-squared 63 per cent) but shows that the lower level of trust held by the market in the smaller CRAs in the post-crisis period is not significant. The variables that explain the abnormal yield are, in line with what is claimed in the literature, the presence of the watch and the absolute value of the notches. The latter, in particular, leads to more accentuated variations of the abnormal return, with a p-value < $1 \%$. This result could be caused by the fact that the minor agencies tend to be more stable in their ratings, but when they change them, they do so with more significant variations. 
Table 10. Determinants of the ABS_CAR - Minor Rating Agencies

The regressions are all conducted with the ordinary least square method. The dependent variable is ABS_CAR i.e. the absolute value of cumulative abnormal return calculated as defined in section 5 . The independent variables are described in Table 7. The specifications from (2) to (4) have been calculated including eight dummies corresponding to the outliers identified in the distribution. The t-stat are reported in brackets under each coefficient. White heteroskedasticity-consistent standard errors and covariance. The specifications (3) and (4) have been calculated including three dummies corresponding to the outliers identified in the distribution. $*$ significant at $10 \%$ level; $* *=$ significant at $5 \%$ level; $* * *=$ significant at $1 \%$ level with a two-tailed test.

\begin{tabular}{|c|c|c|c|c|}
\hline & (1) & (2) & (3) & (4) \\
\hline Subsample & - & - & - & Dummy Stable $=0$ \\
\hline \multirow{2}{*}{ DUMMY_POSTCRISIS } & $-0,83 * *$ & $-0,40$ & & $-0,73$ \\
\hline & $(-2,18)$ & $(-1,28)$ & & $(-1,49)$ \\
\hline \multirow{2}{*}{ VA_CHGNOT } & & & & $2,28 * * *$ \\
\hline & & & & $(2,52)$ \\
\hline \multirow{2}{*}{ WATCH } & & $1,78 * *$ & $1,62 *$ & $2,32 * *$ \\
\hline & & $(2,15)$ & $(1,75)$ & $(2,14)$ \\
\hline \multirow{2}{*}{ DOWN } & & & $1,21 * *$ & \\
\hline & & & $(2,18)$ & \\
\hline \multirow{2}{*}{ BORDER_POSTCRISIS } & & & $-0,82 * *$ & \\
\hline & & & $(-1,93)$ & \\
\hline \multirow{2}{*}{ ANTICIP_BIG } & & & $-0,74$ & \\
\hline & & & $(-1,14)$ & \\
\hline \multirow{2}{*}{ VIX } & $0,25 * * *$ & $0,19 * * *$ & $0,18 * * *$ & $0,26 * * *$ \\
\hline & $(6,47)$ & $(7,06)$ & $(6,32)$ & $(6,31)$ \\
\hline \multirow{2}{*}{ EJR } & & & $0,63 * *$ & \\
\hline & & & $(2,02)$ & \\
\hline \multirow{2}{*}{ GAP_RAT } & & & 0,40 & \\
\hline & & & $(1,15)$ & \\
\hline Adjusted R squared & 0,195 & 0,57 & 0,615 & 0,63 \\
\hline No. observations & 799 & 789 & 667 & 275 \\
\hline
\end{tabular}

\section{Analysis of the CARs for All Rating Actions}

By combining the two samples and analysing the ABS_CAR in light of the independent variables already considered (Table 11), to which we have added the DUMMY_BIG, the accuracy of our theory is strengthened: following the subprime mortgage crisis, the market has less trust in the ratings issued by CRAs. In particular, stocks record lower variations especially where the operators are "forced" by the supervisory rules or by the regulations to intervene. In fact, the DUMMY_NOBORDER*POSTCRISIS appears with an appreciable negative coefficient and with a margin of error of less than $1 \%$. In addition, it appears that the reputational damage weighs more heavily upon the more important CRAs, given the negative coefficient and the high level of significance of the DUMMY_BIG (1). We have isolated the loss of credibility by the major CRAs with respect to the others, considering the subsample made up of rating events formulated by both the Big\&NoBig agencies, in relation to the same issuer (Note 11). The variation of the absolute abnormal return is more contained in the post-crisis, both for those issuers who find themselves in the critical area and for the others, and is lower especially when the rating is expressed by one of the three Big (2). 
Finally, for the same subsample, the introduction of the regressor EJR, in replacement of the DUMMY_BIG, leads to a higher and significant variation of the CAR at $1 \%$. In other words, it would seem that the market has greater faith in the only agency that adopts the subscriber-paid rather than the issuer-paid model (3).

Table 11. Determinants of the ABS_CAR - Minor and major agencies

The regressions are all conducted with the ordinary least square method. The dependent variable is ABS_CAR i.e. the absolute value of cumulative abnormal return calculated as defined in section 5. The independent variables are described in Table 7. All specifications have been calculated including eight dummies corresponding to the outliers identified in the distribution.

The specifications (2) and (3) have been carried out on a subsample of observations that affects issuers covered by both a minor and a major rating agency. The t-stat are reported in brackets under each coefficient. White heteroskedasticity-consistent standard errors and covariance. The specifications (3) and (4) have been calculated including three dummies corresponding to the outliers identified in the distribution.

$*=$ significant at $10 \%$ level; $* *=$ significant at $5 \%$ level; $* * *=$ significant at $1 \%$ level with a two-tailed

\begin{tabular}{|c|c|c|c|}
\hline & (1) & (2) & (3) \\
\hline Subsample & - & Big\&Nobig & Big\&Nobig \\
\hline \multirow[t]{2}{*}{ VA_CHGNOT } & $0,73 * *$ & 0,46 & 0,31 \\
\hline & $(2,30)$ & $(1,54)$ & $(1,1)$ \\
\hline \multirow[t]{2}{*}{ WATCH } & $1,05 * * *$ & 0,69 & 0,62 \\
\hline & $(2,75)$ & $(1,6)$ & $(1,52)$ \\
\hline \multirow[t]{2}{*}{ ANTICIP } & 0,09 & & \\
\hline & $(0,25)$ & & \\
\hline \multirow[t]{2}{*}{ NOBORDER_POSTCRISIS } & $-0,81 * * *$ & $-0,91 * * *$ & $-1,14 * * *$ \\
\hline & $(-3,25)$ & $(-3,12)$ & $(-3,73)$ \\
\hline \multirow[t]{2}{*}{ BORDER_POSTCRISIS } & $-0,045$ & $-0,85^{* *}$ & $-1,02 * *$ \\
\hline & $(-0,14)$ & $(-2,00)$ & $(-2,29)$ \\
\hline \multirow[t]{2}{*}{ DEVST } & & $\mathbf{0 , 8 3} * * *$ & $\mathbf{0 , 8 2} * * *$ \\
\hline & & $(9,15)$ & $(9,19)$ \\
\hline \multirow[t]{2}{*}{ VIX } & $0,19 * * *$ & & \\
\hline & $(\mathbf{9 , 4 1 )}$ & & \\
\hline \multirow[t]{2}{*}{ EJR } & & & $1,12 * * *$ \\
\hline & & & $(3,14)$ \\
\hline \multirow[t]{2}{*}{ DUMMY BIG } & $-0,99 * * *$ & $-1,18 * * *$ & \\
\hline & $(-2,65)$ & $(-3,01)$ & \\
\hline Adjusted R squared & 0,52 & 0,58 & 0,57 \\
\hline No. observations & 1045 & 1033 & 1033 \\
\hline
\end{tabular}

\section{Conclusions}

The results of the analysis confirm the theory that the credibility of the CRAs was strongly affected by the subprime mortgage crisis. The comparison between different type of rating agencies shows that the reputation damage was more significant for the three major players - Moody's, Standard and Poor's and Fitch - whereas the phenomenon affected other minor agencies to a lower extent, even if it has not spared them altogether.

Our analysis shows that the impact of the rating actions on the prices of stocks of the financial intermediaries is lower in the post-crisis period than it used to be, particularly for those issuers that enjoy a higher credit rating. Conversely, the prices of stocks, whose issuers present ratings close to the threshold between investment and 
speculative grade, react to rating actions in a similar manner in the pre- and post-crisis periods, due to the certification value attributed to ratings by current regulations and by-laws. When the rating valuation crosses the boundary between speculative and investment grade, in fact, a large part of institutional investors are forced to modify their portfolio, independently of the trust that they hold in the CRAs. This deduction is confirmed when analysing the impact of the rating actions issued by the minor agencies. The limited use in regulatory terms of the ratings provided by less known CRAs - that are seldom included in the list of agencies accredited by supervisors ensures that the distinction between investment grade and junk grade securities is less significant. In particular, the lower reaction of the market of market prices to rating actions provided by the smaller CRAs, in the post-crisis period, is also confirmed for issuers close to the threshold between investment and junk grade.

As regards the other control variables, our analysis confirms the evidence emerged in previous literature on the topic. The abnormal return is higher when the issuer is inserted in the watch lists, rather than when the actual change in rating opinion occurs. The evidence is stronger in the case of watches issued by the minor CRAs, probably because it is less frequent and therefore the market attributes to them greater informative value. In addition, the reaction of share prices tends to be greater when the change of rating, measured in notches, is consistent and when the volatility level - either market-wide or security-specific - is higher.

Finally, the overall analysis of the 1,609 rating actions issued by the set of agencies included in our sample confirms the loss of credibility of the rating industry in general, highlighting, however, greater reputational damage for Moody's, Standard and Poor's and Fitch, more heavily involved in the events of the subprime crisis. The subsample of 57 financial intermediaries rated by both agencies recorded absolute CAR lower in the post-crisis period especially when the rating action originates from the Big Three. Conversely, the ratings formulated by the Agency EJR, the only entity not applying an issuer-pay business model, produce consistent and significant market reactions.

Given that, in future, the regulatory role of CRAs will be increasingly limited, it is necessary to verify if the loss of credibility identified in the post-crisis period will be recovered, also thanks to new supervisory interventions and the greater competition that is being encouraged. In this sense, a new and interesting field of investigation opens up for the future.

\section{References}

Altman, E.I., \& Rijken, H.A. (2004). How rating agencies achieve rating stability. Journal of Banking \& Finance, (28).

Ammer, J., \& Clinton, N. (2004). Good news is no news? The impact of credit rating changes on the pricing of assets-backed securities. Board of Governors of the Federal Reserve System, International Finance Discussion Papers.

Bank for International Settlements. (2009). Basel Committee on Banking Supervision, Joint Forum. Stocktaking on the Use of Credit Ratings. Retrieved from www.bis.org

Becker, B., \& Milbourn, T. (2010). How did increased competition affect credit ratings?, NBER working paper series, n.1604.

Coffee, J.C. (2010). Ratings Reform: The Good, The Bad, and The Ugly. Columbia Law and Economics Working Paper No. 375.

Deb, P., Manning, M., Murphy, G., Penalver, A., \& Toth, A. (2011). Whither the credit rating industry?, Financial Stability Paper N. 9.

Freeman, L. (2009). Who's Guarding the Gate? Credit Rating Agency Liability as Control Person in the Subprime Credit Crisis. Vermont Law Review, 33.

Goh. J., \& Ederington, L.H. (1993). Is a bond rating downgrade bad news, good news or no news for stockholders?. The Journal of Finance, 48, 2001-2008.

Gropp, R., \& Richards, A.J. (2001). Rating agency actions and the pricing of debt and equity of European banks: what can we infer about private sector monitoring of bank soundness?. Economic Notes, Monte dei Paschi di Siena, 30, 373-398.

Grothe, M. (2013). Market pricing of credit signals. European Central Bank, Working Paper Series, n. 1623.

Hand, J.R., Holthausen, R. W., \& Leftwich, R.W. (1992). The effect of bond rating agency announcements on bond and stock prices. The Journal of Finance, 47, 733-752. 
Hull, J., Predescu, M., \& White, A. (2004). The relationship between credit default swap spreads, bond yields and credit rating announcements. Journal of Banking and Finance, (28), 2789-2811.

International Monetary Fund. (2010). The uses and abuses of sovereign credit ratings. Retrieved from www.imf.org

Katz, S. (1974). The price and adjustment process of bond rating reclassifications: a test of bond market efficiency. The Journal of Finance, 29(2), 551-559.

Kiff, J., Novak, S., \& Schumacher, L. (2012). Are rating agencies powerful? An investigation into the impact and accuracy of sovereign ratings. International Monetary Funds, Working Papers.

Levin, C., \& Coburn, T. (2011). Wall Street and the financial crisis: anatomy of a financial collapse. United States Senate, Permanent subcommittee on investigations.

Linciano, N. (2004). L'impatto sui prezzi azionari delle revisioni dei giudizi delle agenzie di rating. Evidenza per il caso italiano, Banca Impresa Società, n. XXIII.

Linciano, N. (2008). La crisi dei mutui subprime. Problemi di trasparenza e opzioni di intervento per le autorità di vigilanza. Quaderno Consob n.62.

Micu, M., Remolona, E., \& Woolridge, P. (2006). The price impact of rating announcements: which announcements matters. Bank for International Settlements, Working Papers, n. 207.

Norder, L., \& Weber, M. (2004). Informational efficiency of credit default swap and stock markets: the impact of credit rating announcements. Journal of banking and finance, (28), 2813-2843.

Partnoy, F. (1999). The Siskel and Ebert of financial markets: Two Thumbs Down for the Credit Rating Agencies. Washington University Law Quarterly, 77.

Partnoy, F. (2006). How and Why Credit Rating Agencies Are Not Like Other Gatekeepers, Legal Studies Research Paper Series Research, Paper N. 07-46.

Partnoy, F. (2009). Overdependence on Credit Ratings was a Primary Cause of the Crisis. San Diego Legal Studies Paper N. 09-015.

Petit, N. (2011, December). Credit Rating Agencies the sovereign debt crisis and competition law. European Competition Journal, 7(3).

Pinches, G.E., \& Singleton, J.C. The adjustment of stock prices to bond rating changes, The Journal of Finance, 33, 29-44.

Richards, A., \& Deddouche, D. (1999). Bank rating changes and bank stock returns: puzzling evidence from emerging markets. International Monetary Funds, Working Papers, n. 151.

Steiner, M., \& Heinke, V. G. (2001). Event study concerning international bond price effects of credit rating actions, International Journal of Finance and Economics, 139-157.

Szweitzer, R., Szewczyk, \& Varma, R. (2001). The effect of bank debt downgrades on stock prices of other banks. The Financial Reviews, 139-156.

White, L. J. (2002). The Credit Rating Industry: An Industrial Organization Analysis. In Levich R., Reinhart C., and Majnoni G., Kluwer (Eds.), Ratings, Rating Agencies, and the Global Financial System.

White, L.J. (2010). The Credit Rating Agencies. Journal of Economics Perspectives, 24(2), Spring, 2.

\section{Notes}

Note 1. "Traditionally, investments holding AAA ratings have had a less than $1 \%$ probability of incurring defaults. But in 2007, the vast majority of RMBS and CDO securities with AAA ratings incurred substantial losses; some failed outright. Analysts have determined that over $90 \%$ of the AAA ratings given to subprime RMBS securities originated in 2006 and 2007 were later downgraded by the credit rating agencies to junk status. In the case of Long Beach,75 out of 75 AAA rated Long Beach securities issued in 2006, were later downgraded to junk status, defaulted, or withdrawn. Investors and financial institutions holding the AAA rated securities lost significant value. Those widespread losses led, in turn, to a loss of investor confidence in the value of the AAA rating, in the holdings of major U.S. financial institutions, and even in the viability of U.S. financial markets." (Levin C., Coburn T., 2013, Wall Street and the financial crisis. Anatomy of a financial collapse, United States Senate, Permanent Subcommittee on Investigations, p. 6). 
Note 2. This paper is part of a larger research project undertaken by a research group of the University of Turin. Using a similar methodology and with the same research question, a different sample made up of banks and non-financial companies belonging to the Euro Stoxx 50, Usa Stoxx and Asia-Pacific Stoxx was analysed. The paper Damilano, Isaia, Rovera (2014) presents the results of the analysis, focusing in particular on the weight of geographical and sectorial cross-sectional differences.

Note 3. "The rating agencies favor that term 'opinion' because it supports their claim that they are 'publishers'. One implication is that the credit rating agencies thus enjoy the protections of the First Amendment of the U.S. Constitution when they are sued by investors and by issuers who claim that they have been injured by the actions of the agencies". See WHITE L.J. (2010), The Credit Rating Agencies, Journal of Economics Perspectives, Volume 24, Number 2, Spring, p.212; FREEMAN, L. (2009), Who's Guarding the Gate? Credit Rating Agency Liability as Control Person in the Subprime Credit Crisis, in Vermont Law Review, vol. 33, p. 585.

Note 4. "When the CRAs principally rated corporate bonds, no one client accounted for $1 \%$ of their business (because even large corporations went to the bond market only intermittently). But as structured finance became the CRAs 'principal profit center', the rating agencies faced a limited number of large investment banks that brought deals to them on a continuing basis (and thus could threaten to take a substantial volume of business elsewhere, if dissatisfied)". See COFFEE J.C. (2010), Ratings Reform: The Good, The Bad, and The Ugly, Columbia Law and Economics Working Paper No. 375.

Note 5. Rating stability reduces the need for frequent and high-cost changes in the composition of the portfolio. See ALTMAN E.I. - RIJKEN A.H. (2004), How rating agencies achieve rating stability, in Journal of Banking \& Finance, no. 28, pp. 2679-2714.

Note 6. The first attempt to set up a supervision model for agencies dates back to 2004 with the adoption by the International Organization of Securities Commissions of a Code of Conduct Fundamentals for Credit Rating Agencies. However, the IOSCO code did not have a great impact since its adoption was voluntary. Only in 2006 was the first legislation regulating CRAs introduced in the USA with the Credit Rating Agency Reform Act of 2006 (CRARA). Eventually, in 2009, with the subprime crisis, American authorities were forced to introduce the Dodd-Frank Act, a set of new and stricter measures to combat the most controversial and damaging aspects relating the CRAs' activity. In Europe, the first CRAs' policies date back to 2009 (EC Reg. No. 1060/2009) supplemented by two subsequent regulations: EU Reg. no. 513/2011 and EU Reg. no. 462/2013.

Note 7. Except for R\&I, they are credit rating agencies registered as NRSRO. R\&I is an eligible External Credit Assessment Institution (ECAI) in Japan, Hong Kong and Malaysia.

Note 8 . They belong to the following, by category: Diversified banks, Regional banks, Diversified capital market and Investment banking \& brokerage.

Note 9. Those guidelines, incorporated in EU Regulation no.462/2013, invite issuers intending to instruct more than one agency to choose, within the specific register, at least one entity that holds a market share no greater than $10 \%$.

Note 10. The presence of a credit watch increased or reduced the score of 0.25 depending on whether the watch was negative or positive.

Note 11. They are 57 issuers highlighted in Table 3. 